Logos Universality Mentality Education Novelty, Section: Social Sciences

ISSN: $2284-5747$ (print), ISSN: $2284-5747$ (electronic)

Covered in: CEEOL, Index Copernicus, Ideas RePEc, EconPapers, Socionet

\title{
THE ROLE OF AFTERSCHOOL PROGRAMS IN THE EDUCATIONAL ACTIVITY
}

\section{Gabriela BEREA}

Logos Universality Mentality Education Novelty, Section:

Social Sciences, IV (1), 147-155

The online version of this article can be found at:

http://lumenjournals.com/social-sciences/

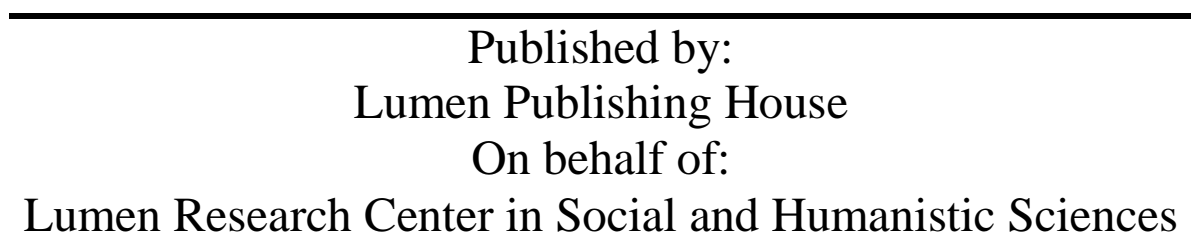




\title{
The Role of Afterschool Programs in the Educational Activity
}

\section{Gabriela BEREA ${ }^{1}$}

\begin{abstract}
The article talks about the motivation behind After School programs, beginning with current tendencies to expand educational activities from the school itself towards other providers of educational activities and services.

Educational institutions are functioning in a broad and complex social context - the global society as global social system (national, state system). This system has various influences over educational institutions - over the final scope of education (aims and objectives), discipline content, organization of institutions and educational system, administrative and legal regulations. From a different perspective, the same institutions are functioning in a specific social context, in a local and regional community that provides the students but also comes with expectations to which educational institutions must respond.

The school is an institution that functions in a community made up of many educational factors: family, authorities, governmental organizations and NGOs. They also offer educational alternatives. All types of school organizations are subjected to pressure coming from different factors: local ideological groups, political systems, economical realities and other social tendencies. Educational institutions are therefore influenced by economical, political, cultural and ideological trends. Institutions that host After School rely on the environment in which the function, when it comes to accessing material, financial, buman and informational resources.
\end{abstract}

\section{Keywords:}

After School program, education, educational institutions, organizations, community, family, authorities.

1 Professor PhD, Liceul Teoretic "Vasile Alecsandri”, Iaşi, România, gabiberea16@yahoo.com,0741057579.

Berea, G. (2015). The Role of Afterschool Programs in the Educational Activity. Logos Universality Mentality Education Novelty, Section: Social Sciences, IV (1), 147-155. 


\section{Educația - factor definitoriu în construcția socială}

Scopul educației se regăseşte în construcția fiinţei sociale a fiecărui individ. Societatea vede în fiecare generaţie un teren propice pentru a cultiva "bazele umanitătiii", adică toate componentele culturii şi civilizației din care face parte. Copilul vine în contact cu un anumit tip de societate; nu există o "educație universală", valabilă în toate societățile şi în toate perioadele istorice. Educația este diferită în funcție de societăți, contexte etno-socio-culturale, în diverse perioade de timp, iar rezultatul este tipul omului ideal pentru sociocultura care îl formează, în care trăieşte.

Ecaterina Vrăşmaş face distincția între urmatorii termeni: educația părinților, educația parentală, educația familială.

Educatia părinților face trimitere la "susținerea parentalității deja manifeste" având deci un sens mai restrâns decât educaţia parentală.

Educația parentală se adresează atât părinţilor cât şi viitorilor părinți, este o activitate de formare şi include orice tip de acțiune educativă de informare, "sensibilizare, învăţare, antrenare, clarificare referitoare la valori, atitudini si practici parentale de educație".

Educaţia familială are un sens mai larg vizând "construirea deprinderilor, valorilor şi normelor vieții în comun în familie, avându-i în vedere pe toți membrii familiei” (Vrăşmaş, E., 2002, pag. 66).

\section{Necesitatea programelor After school în contextul educaţional}

Socializarea este un proces foarte complex, ce presupune multiple interacţiuni între individ, în calitate de socializat si societate, în calitate de socializator. Prin procesul de socializare, societatea exercită o putere considerabilă asupra noilor membri pe care îi învață cum ar trebui sa se comporte. În sistemele complexe, precum cel educațional, această pregătire se poate realiza formal, sistematic. Volumul de cunoştinţe necesare este atât de mare, încât este nevoie de pregătire continuă, sistematică. În accepțiune sociologică, conceptul de "educație" desemnează o astfel de pregătire, deosebită de modurile de socializare mai puțin formale (A. Johnson, 2007, pag.135). Şcolile sunt instituțiile sociale în care se desfăşoară educația. Prin educație sunt create efecte directe şi indirecte ale clasei sociale a părinţilor asupra ocupației copiilor.

Referințele sunt legate, în articolul de față, de analiza şcolii, clasei, curriculum-ului, efectului educație de tip after school, transmiterii 
cunoştinţelor, metodelor, în încercarea de a evidenția în ce măsură educația realizată în acest tip de programe poate să controleze comportamentele.

Pornind de la întrebările: "Comportamentul copiilor, al tinerilor, este "coordonat" de un anumit tip specific educație? Există un "conformism social" sau o "respingere" in ceea ce privește educația after school? Prin acest program este asigurată de către şcoală "egalitatea de şanse"?, prezint o schemă logică simplă, care arată legătura dintre elementele legate de originea socială, educaţie şi familie. (vezi figura 1)

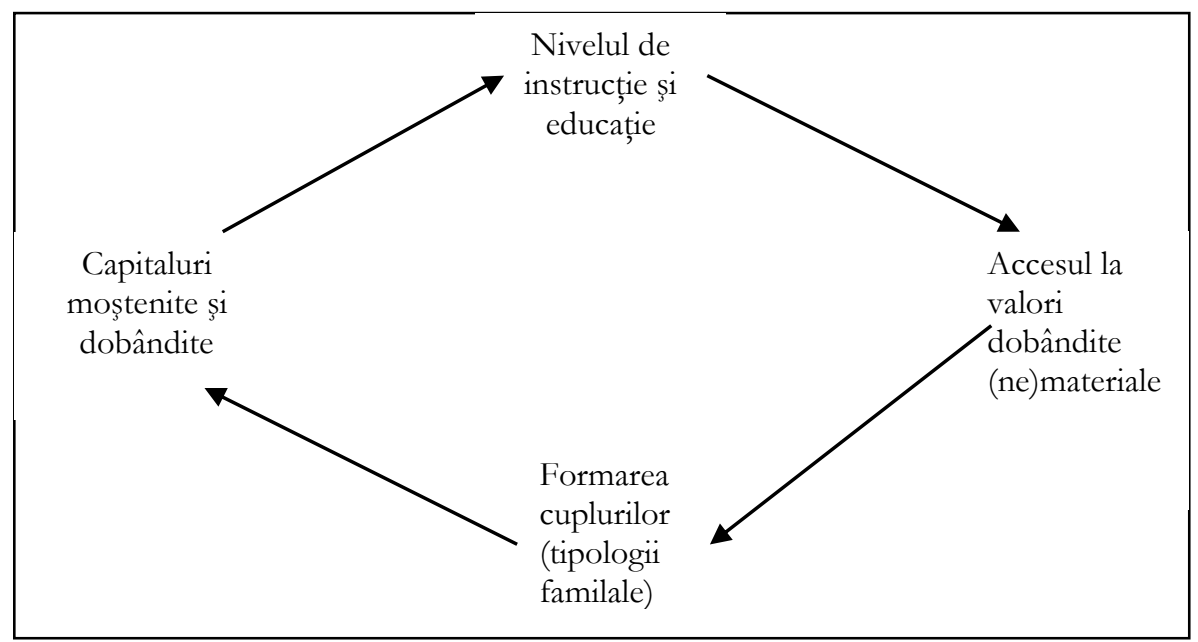

Figura 1 Schemă simplă - originea socială, educație şi familie

Pornind de la această schemă am încercat să stabilesc punctul e plecare pentru a-mi explica dacă educația de tip after school este o condiție pentru reuşita şcolară.

Performanțele de învăţare ale copiilor sunt influențate de capitalul social intrafamilial (relaţiile dintre membrii ei, în special raporturile dintre părinţi şi copii) şi de cel extrafamilial. Potrivit lui James Coleman, absența unui părinte sau angajarea lui pe piaţa muncii, ceea ce determină lipsa prelungită de acasă, duce la o deficiență a capitalului social intrafamilial. Cu cât părinții petrec mai mult timp cu copiii, se implică mai mult în educația lor, le oferă modele pozitive de învăţare şi le solicită rezultate şcolare, cu atât se va transfera mai uşor capitalul cultural de la o generație la alta. Folosindu-se de date din diverse studii, 
Coleman susţine că abandonul şcolar este semnificativ mai mare în cazul elevilor care au un singur părinte şi au mai mulți frați, ceea ce duce la o diminuare a atenției pe care o poate acorda acel singur părinte unuia dintre copii. La fel, o rată mare a abandonului se înregistrează la copiii ai căror părinți nu aşteaptă de la copii să frecventeze un colegiu. Rata abandonului pentru elevii proveniţi din familii în care ambii părinţi sunt prezenți, au aspirații legate de facultate şi au un singur frate este de 8,1\%, în timp ce, în cazul elevilor cu un părinte absent, cu patru fraţi şi de la care nu se aşteaptă frecventarea colegiului, acest indice este de $30,6 \%{ }^{2}$.

Capitalul social extrafamilial poate fi găsit în relațiile dintre părinţi, în închiderea relațiilor dintre copii şi părinți, părinții unor copii care sunt prieteni sunt la rândul lor prieteni, şi în relațiile dintre părinţi şi instituțiile comunității. Înțelegerea funcționării impactului rețelor sociale asupra performanțelor şcolare ale elevilor a condus la recomandări de politici sau la cererea directă a părinților de înlocuire a mecanismelor de supraveghere destructurată din familii în care ambii părinți lucrează sau din familii monoparentale cu instituții care să preia unele dintre funcțiile familiilor. Programele after school au apărut ca soluții în acest sens.

In acest sens am realizat un studiu cu scopul de a identifica raportul dintre cererea și oferta educațională, realizată prin programele after school, programe înființate ca urmare a supraincărcării orarului lor de muncă al părinţilor, ce a avut ca şi consecinţă diminuarea timpului aferent educației şi supravegherii propriului copil.

Populatia la care fac referire în prezentul studiu este cea a părinților care şi-au înscris copiii în after school, iar eşantionul este compus din 63 de subiecți.

Rezultatele reflectă realitatea programelor de tip after school şi a copiilor care beneficiază de această formă de educație. De asemenea, în acest studiu $\mathrm{m}$-am bazat şi pe datele statistice de ordin cantitativ accesibile, coroborate cu constatările efectuate anterior prin prisma experienței personale avute în domeniu.

2 În Revista Calitatea vieții XXII, Nr. 3, 2011, în Programul Şcoală după şcoală, pag.227-239 Ioan Mărginean, Gabriela Neagu, Flavius Mihalache, Marian Vasile prezintă „efectul şcoală” asupra performanţelor educaţionale ale elevilor şi factori care favorizează un parcurs şcolar pozitiv. 
În tabelul următor sunt menționate aceste efectele poxitive şi negative asupra copiilor sub impactul programului after school, din perspectiva părinților, ca beneficiari indirecți ai acestui program.

Tabelul 2. Efecte pozitive şi negative remarcate la copii din cadrul programelor After school în viziunea părinților

\section{Efecte pozitive}

Schimbare comportamentală

Responsabilitate

Sociabilitate

Comunicare

Conştiinciozitate

Perseverență

Creativitate

Însuşirea de noi cunoştințe

Valori (stimă, încrederea în sine, independență)

\section{Efecte negative}

Oboseala.

Corectarea temelor în loc de explicarea a ceea ce este greşit.

Copilul este mai aglomerat.

Schimbarea comportamentală - tendinţa de fi mai ordonat, ponderat, preocupat, interesat de învăţare, de a avea o atitudine disciplinată, o atenție sporită la lecții, de a se purta mai frumos, calm, de a se simți mai important, de a-şi organiza activităţile, toleranța la programul prelungit, spiritul competitiv - dovedesc progresul în dezvoltarea copiilor care urmează un program educativ de tip After school.

De asemenea, în opinia părinților, responsabilitatea copilului pentru modul în care îşi organizează timpul şi apoi pentru rezultatele la învăţătură obținute ca urmare a gestionării timpului de după şcoală, conduc la motivația sa ulterioară, la dorința de a învăța, de a progresa.

Sociabilitatea (lucrul în echipă, prietenia, relațiile mai bune cu ceilalți) este cel de al treilea efect amintit de către subiecții chestionați în acest studiu, fapt care confirmă importanța socializării prin participarea la astfel de programe. Sociabilitatea începe din copilărie şi se produce pe măsură ce individul dobândeşte noi „,roluri’. Ajută, mai ales în rândul celor mici, la formarea unui „Sine” social. Important de menționat aici este faptul că „alții” nu sunt doar colegii din propria clasă ci şi copiii şi profesorii din alte şcoli sau clase, iar activităţile desfăşurate sunt diferite de cele din orele de la şcoală. Interacțiunea, modul în care socializează copilul în cadrul programelor AS ar putea fi considerată una necesară pentru sistemul educațional. Socializarea în sens larg, sociabilitatea în 
sens restrâns modelează sentimentele, gândurile şi comportamentul acestor copii care beneficiază şi de un alt tip de educație decât cel formal oferit de şcoală.

Socializarea anticipativă este tipul semnificativ de socializare căruia ii face loc programul after school. Socializarea este anticipativă când priveşte un rol pe care persoana supusă socializării îl va îndeplini cândva în viitor (Johnson, A,. G., 2007, pag. 321). În cadrul acestui tip de program, mai ales în activităţile recreative sau în unele opționale desfăşurate, cum ar fi orele de teatru, sau dans elevii îmbracă în joaca lor comportamentul părinţilor, practică aspecte de bază ale unor roluri adulte care îi aşteaptă abia peste mulți ani. Mare parte a exemplelor de viaţă şi a tiparelor comportamentale sunt furnizate de către părinţi şi învăţători, pe care copiii şi le însuşesc, imitându-i cu uşurinţă. La fel se întâmplă şi în contactul cu cei de aceeaşi vârstă cu ei; manierele, stilurile vestimentare, modul de exprimare sunt împrumutate de la unii la alții. Modalitatea de desfăşurare a unui program educativ care nu se identifică $\mathrm{cu}$ rigurozitatea programului şcolar oferă premise generoase de dezvoltare a socializării anticipative.

Comunicarea, spiritul de echipă, modul de interacțiune, atitudinile surprinse în cadrul acestui studiu, le-am analizat din perspectivele relațiilor elev-elev, elev-cadru didactic, elev-părinte. Pornind de la datele innregistrate în prezentul studiu am realizat că este necesar să identific dificultăţile apărute pe parcursul comunicării, să desprind situațiile de eşec sau reuşită şcolară, punctând acele cauze şi efecte care au un rol important în realizarea comunicării actorilor sociali implicaţi în cercetare. Toate aceste aspecte le-am urmărit, analizat şi interpretat în studiile următoare ale cercetării de față.

Dobândirea de noi cunoştințe (cursuri pictură, limbi străine, şah, creativitate) au un rol important în dezvoltarea copiilor.

Efectele negative prezentate de cei chestionați sunt cu mult reduse față de cele pozitive. Datele confirmă utilitatea şi necesitatea programelor educative, iar acest lucru este cu atât mai credibil cu cât vine din partea subiecților cercetării ce au copii care beneficiază de un program prestabilit, cu efecte pozitive asupra eficientizării supravegherii în realizarea lecțiilor şcolare, precum şi a creşterii gradului de responsabilitate. 
Unul dintre aspectele urmărite în cadrul studiului face referire la conturarea trăsăturilor dominante ale copiilor şi la modul de manifestare a acestora. Printre răspunsuri se disting atât trăsături pozitive ca: ambiție, comunicare, creativitate, imaginație, curiozitate, independență, perseverență, dorința de cunoaştere, cât şi trăsături negative, relevate prin: timiditate (ce se manifestă prin descurajarea rapidă, sensibilitate manifestată prin plâns, accese de orgolii, fire retrasă, încăpăţânare, neîncrederea în cunoştintele dobândite); superficialitate, neatenție, rivalitate.

Preocupările profesionale conduc la o diminuarea a timpului liber petrecut în cadrul familiei. Părinții nu doar că nu reuşesc să satisfacă nevoile de cunoaştere ale copiilor, ci recurg în mod involuntar la suprasolicitarea acestora prin intermediul programului AS. Acest fapt este datorat, în opinia subiecților, supraîncărcării propriului program de lucru. În acest fel timpul destinat socializării familiei se diminuează continuu, în favoarea asigurării necesităţilor materiale. Familia societăţii ieșene actuale a pierdut mult din caracterul ei tradițional. Devine din ce în ce mai elocvent faptul că mediul familial reprezintă cadrul de realizare a intereselor individuale ale membrilor săi, iar în acest context rolul socializator al familiei capătă noi conotații.

La întrebarea „Ce laturi ale caracterului îi multumeşte la copil / copii și consideră că ar trebui dequoltate şi ce laturi îi nemultumeste și trebuie corectate, cei mai mulți dintre părinți se declară mulțumiţi de trăsăturile pozitive descrise (comunicare, bunătate, ambiție, independență, conştiinciozitate, interesul pentru învăţare, imaginația, perseverenţa, altruismul, competitivitate) şi consideră că ar trebui dezvoltate mai mult. Aspectele care î nemulțumesc pe subiecții studiului de față fac referire la timiditate, superficialitate, egoism, nesiguranță, izolare, minciună, încăpăţânare.

Mijloacele prin care poate fi atras copilul în activităţi ce ar contribui la dezvoltarea sa, în opinia părinților, sunt activitățile artistice, cele extraşcolare ,prin sarcini foarte bine stabilite, prin recompensă, competiție, comunicare, creativitate, joacă, vorbă bună".

Din analiza datelor studiului de faţă rezultă că de cele mai multe ori copiii sunt atraşi în astfel de activități prin acțiuni ce presupun mişcare, încurajare, jocuri educative, comunicare, înțelegere, prin forța exemplului, prin recompensa rezultatelor dar şi prin stimularea lor afectivă, ei fiind motivați astfel spre acțiune şi învăţare. Unii părinți 
amintesc de modalitatea evaluării prin acordarea de calificative, diplome şi participarea la numeroase concursuri; astfel copilul poate fi încurajat şi motivat să participe în orice activitate constructivă.

\section{Concluziile studiului}

Rezultatele studiului aduc în atenție faptul că activităţile desfăşurate de copii în timpul liber au rolul de a consolida bazele formate în decursul procesului instructiv-educativ desfăşurat în instituțiile şcolare. Programelor de după şcoală le revine misiunea de a gestiona acest timp, cu scopul de a contribui în mod pozitiv la dezvoltarea socială a copiilor. Activităţile propuse în programul after school urmăresc aşadar atragerea copiilor în câmpul acțiunii educative, spre a nu fi lăsaţi în voia dezordinii, la dispoziţia întâmplării, fără a pierde însă din vedere că odihna, recreerea, acțiunile distractive şi recreative se impun a face parte din paleta de activităţi disponibile pentru timpul liber al fiecărei zile.

Aspectele identificate în prezentul studiu demonstrează interesul pe care-l acordă părinții progresului şcolar al copilului pe de o parte şi modalitatea prin care încearcă să ducă acest deziderat la stadiul de realitate atunci când programul supraîncărcat nu permite îndeplinirea completă a rolului de părinte. Programului educativ after school pune accent pe importanța comportamentului şi atitudinii în dezvoltarea socială a copilului, dezvoltare care se produce stadial şi individual, sub impactul factorilor intrinseci şi extrinseci şi pe supravegherea şi îndrumarea acestuia în traseul educațional. Elementele evidențiate în cadrul studiului conduc către schimbarea comportamentală a elevilor pe perioada frecventării programului. Programul de tip after school pare a fi unul eficient şi necesar în dezvoltarea socială a copiilor, sub aspectul educării, responsabilizării şi socializării, conform opiniilor rezultatelor obținute în studiul de faţă.

\section{Acknowledgment}

This paper is a result of a research made possible by the financial support of the Sectoral Operational Programme for Human Resources Development 2007-2013, co-financed by the European Social Fund, under the project POSDRU/159/1.5/S/132400 - "Young successful researchers - professional development in an international and interdisciplinary environment". 


\section{References}

Coleman, James The American Journal of Sociology, Vol. 94, Supplement: Organizations and Institutions: Sociological and Economic Approaches to the Analysis of Social Structure (1988), pp. S95-S120.

Durkheim, Emile, Educatie si sociologie, Bucuresti, Editura Didactica si Pedagogica (1980).

Johnson, Allan G. Dictionarul BLACKWELL de sociologie. Ghid de utilizare a limbajului sociologic, traducere din engleza de S. G. Dragan si V. Russo, prefata de Septimiu Chelcea, Editura Humanitas, Bucuresti.

Marginean, Ioan; Neagu, Gabriela; Mihalache, Flavius, Marian Vasile Revista Calitatea vietii XXII, Nr. 3, (2011) in Programul Scoala dupa scoala, pag. 227-239.

\section{Biodata}

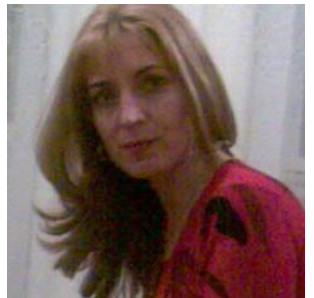

Teacher at "Vasile Alecsandri" Theoretical High School, Iasi, Costache Negri Str. No.50. web: www.lvais.ro. Main activity is teaching grades I-IV. Has studied at "Vasile Lupu" Pedagogical High School in Iasi and obtained a bachelor degree from "Al. I. Cuza" University in Iasi - Philosophy and Political Sciences Faculty. Presently, I'm managing an After School program through "Europrecepta" www.europrecepta.ro.

I have been working in the educational field for the last 27 years. I am interested in sociology and education. 